\title{
ANTROPOLOGIA FILOZOFICZNA W UJECCIU STEFANA STRASSERA
}

Niemal wszystkie prace Strassera dotyczą wprost lub ubocznie antropologii filozoficznej. W całości zaś problematyce tej poświęcone są trzy dzieła: „Phénoménologie et sciences de l'homme” (1967), „Le problème de l'âme” (1953) i „Das Gemüt” (1956). W pierwszym dziele omawia Autor teorię empirycznych nauk o człowieku, by przejść następnie do charakterystyki właściwej antropologii filozoficznej. Dwa następne pisma są oryginalną próbą zbudowania niektórych części filozofii człowieka: zajmują się zagadnieniem naszego ja oraz emocjonalną stroną człowieka.

Strasser, wydawca niemieckiego tekstu „Medytacji Kartezjańskich” Husserla (1950), opowiada się w zasadzie za fenomenologią. Nie jest jednak fenomenologiem jednostronnym: w jego pismach obok fenomenologów pojawiają się także inni filozofowie, św. Tomasz, Hegel, Heidegger $i$ inni. A. De Waelhens napisał o Strasserze, że ma on głębokie zaufanie do jedności prawdy filozoficznej i doskonałą elastyczność poznania historycznego ${ }^{1}$. Faktycznie w pracach Strassera fenomenologiczna filozofia człowieka harmonijnie się kojarzy $z$ rezultatami badań i refleksji przedstawicieli innych kierunków. Poczucie jedności prawdy filozoficznej i dobre rozumienie idei zawartych w tradycji umożliwiają Autorowi owocne zestawienia i porównania.

Strasser wyróżnia antropologię pozytywną i filozoficzną. Antropologia pozytywna obejmuje wszystkie empiryczne nauki o człowieku, jak np. socjologię, etnologię, historię i tym podobne. Nauki te zajmują się człowiekiem jako osobą, przy czym osoba oznacza tu całość elementów duchowo-somatycznych, a nie tylko warstwę lub centrum aktywne czysto duchowe. Przedmiotem więc tych nauk jest to, co charakterystyczne dla

1 Przedmowa do: Le problème de l'âme. Etudes sur l'objet respectif de la psychologie métaphysique et de la psychologie empirique, Louvain-Paris 1953, VI. 
człowieka, co odróżnia go od innych istot na ziemi. Dlatego Strasser nie zalicza do antropologii pozytywnej takich nauk, jak np. anatomia lub fizjologia człowieka, gdyż nauki te zajmują się człowiekiem jako częścią przyrody i należą do dyscyplin przyrodniczych ${ }^{2}$.

Obok antropologii pozytywnej potrzebną jest także antropologia filozoficzna, gdyż człowiek jako animal metaphysicum nie może być w pełni poznany metodami nauk empirycznych. Zresztą nawet rzeczywistość otaczająca człowieka nie będzie należycie dostępna dla niego, jeśli nie pozna dobrze swej własnej egzystencji, środowisko bowiem ludzkie w ogromnej swej części jest tworem tej egzystencji ${ }^{3}$.

Strasser sądzi, że początki antropologii filozoficznej już istnieją. Na pograniczu empirycznych nauk o człowieku i filozofii od dawna uformowały się takie dyscypliny szczegółowe, jak filozofia świadomości moralnej, kultury, języka, grup społecznych i inne. Antropologia filozoficzna jest być może powołana do tego, by zgrupować wokół siebie te metaphysicae speciales ${ }^{4}$.

Antropologia fenomenologiczna jest zdaniem Strassera filozofią, która opisuje i interpretuje egzystencję ludzką w jej relacjach dialektycznych do innych istot ${ }^{5}$. Tak pojęta fenomenologia ma charakter hermeneutyczny, intuicyjny i dialektyczny.

Hermeneutyka filozoficzna rozwija się głównie od czasu, gdy Heidegger poświęcił jej szereg uwag w drugim rozdziale swej wstępnej części „Sein und Zeit"6, choć jej początki zjawiają się znacznie wcześniej. Strasser, nawiązując do Heideggera, nie sądzi, by hermeneutyka miała być przeciwną fenomenologii. Poszukiwanie sensu (zwłaszcza pierwotnego, fundamentalnego) rzeczywistości ludzkiej, sensu, który nie jawi się

2 Phénoménologie et sciences de l'homme. Vers un nouvel esprit scientifique Louvain-Paris 1967, 17-21. O stosunku nauk humanistycznych do przyrodniczych por. S. Kamiński, Pojęcie nauki i klasyfikacja nauk, Lublin 1970, 256-265. O względnej immanencji człowieka w stosunku do przyrody por. Ks. K. Kłósak, Immanencja $i$ transcendencja człowieka $w$ odniesieniu do przyrody, w: $O$ Bogu $i$ człowieku, I, Warszawa 1968, 165-177.

3 Phénoménologie, 238.

4 Phénoménologie, 249.

5 Phénoménologie, 282: „Par phénoménologie, nous entendons une philosophie qui décrit et interprète l'existence humain dans ses rapports dialectiques avec d'autres existants".

6 Sein und Zeit, Halle 1931, 37-38: „Phänomenologie des Daseins ist Hermeneutik in der ursprünglichen Bedeutung des Wortes, wonach es das Geschäft der Auslegung bezeichnet. Sofern nun aber durch die Aufdeckung des Sinnes des Seins und der Grundstrukturen des Daseins überhaupt der Horizont herausgestellt wird für jede weitere ontologische Erforschung des nicht daseinsmässigen Seienden, wird diese Hermeneutik im Sinne der Ausarbeitung der Bedingungen der Möglichkeit jeder ontologischen Untersuchung. Und sofern schliesslich das Dasein den ontologischen Vorrang hat vor allem Seienden - als Seienden in der Möglichkeit der Existenz, erhält die Hermeneutik als Auslegung des Seins des Daseins einen spezifischen dritten - den, philosophisch verstandenen, primären Sinn einer Analytik der Existenzialität der Existenz". 
bezpośrednio w fenomenach, ale który może być odkryty, gdyż pewne znaki wskazują na jego istnienie, wydaje się mu czymś koniecznym. W związku z tym próbuje podać pojęcie sensu. Zdaniem Strassera scholastycy nie zastanawiali się wprost nad sensem. Implicite jednak mówili o nim, mianowicie wtedy, gdy rozważali własności przestępne bytu: dobro, prawdę, piękno. Sensem jest to, co jest wspólne dla własności przestępnych bytu i co można nazwać pierwszą doskonałością, prima perfectio ${ }^{7}$.

$\mathrm{Z}$ antropologią hermeneutyczną łączy się problem rozumienia. Strasser sądzi, nawiązując do Dilthey'a i Schelera, że rozumienie (Verstehen) domaga się udziału czynników pozarozumowych. Przeżywanie odtwórcze (Nacherleben) i współodczuwanie z innymi (Mitfühlen) uważa za wstępny warunek rozumienia rzeczywistości ludzkiej. Nie można należycie rozumieć egzystencji ludzkiej, nie wczuwając się w jej wartości, motywy, cele. Studium człowieka zawsze staje wobec relacji podmiot-podmiot, a nie wobec relacji podmiot-przedmiot, jak to jest w naukach przyrodniczych. Dlatego każda autentyczna antropologia musi uwzględniać w miarę swych możliwości wszystkie przeżycia egzystencji ludzkiej. W związku z tym krytykuje Strasser ideę obserwatora bezinteresownego, o której mowa w pismach Husserla. Opowiadając się bez zastrzeżeń za zdrowo pojętym racjonalizmem, sądzi Autor, że można pogodzić racjonalizm z tak opisanym rozumieniem, jeśli się tylko będzie miało odpowiednią postawę krytyczną i dialektyczną ${ }^{8}$.

Antropologia fenomenologiczna ma także charakter intuicyjny. Intuicja oczywiście oznacza tu podstawowy zabieg fenomenologów, przy którym dokonuje się wglądu, analizy i opisu fenomenu jawiącego się bezpośrednio w świadomości ${ }^{9}$. Wartość intuicji ma jednak pewne granice. Strasser sądzi, że starsza generacja fenomenologów przeceniała zdolności poznawcze intuicji. Oczywistość rzeczy, jaka się jawi w fenomenach, nie

7 Phénoménologie, 220-229, 240-221. O hermeneutyce $\mathrm{w}$ fenomenologii por. H. Spiegelberg, The phenomenological movement. A historical introduction. The Hague 1960, II, 692-698. Współczesne zagadnienia hermeneutyki filozoficznej omawiają m. in.: E. Betti, Teoria della interpretazione, Milano 1955; H. G. Gadamer, Wahrheit und Methode. Grundzüge einer philosophischen Hermeneutik, Tübingen 1960; P. Ricoeur, De l'interprétation, Paris 1965; K. Lehmann, Hermeneutik, Sacramentum Mundi, II (1968) 676-682.

8 Phénoménologie, 163-167, 184-186. Por. Das Gemüt. Grundgedanken zu einer phenomenologischen Philosophie und Theorie des menschlichen Gefühlsleben, Utrecht-Antwerpen-Freiburg 1956, 72-84. O rozumieniu por. J. Wach, Das Verstehen, I-III, Hildesheim 1966. Filozofię człowieka Schelera omawia ks. F. Znaniecki, Antropologia Filozoficzna Maxa Schelera, „Studia Pelplińskie”, (1969) 143-179.

9 Phénoménologie, 258-261. Por. Husserl, Idee czystej fenomenologii i fenomenologicznej filozofii, BKF, Warszawa 1967, 78-79: „Żadna teoria, jaką by można wymyślić, nie może nas zwieść na manowce co do tej zasady wszystkich zasad: że każda źródłowo prezentująca naoczność jest źródłem prawomocności poznania, że wszystko, co się nam w intuicji źródłowo (by się tak wyrazić: w swej cielesnej rzeczywistości) przedstawia, należy po prostu przyjąć jako to, co się prezentuje, ale także jedynie w tych granicach, w jakich się tu prezentuje". 
jest tak pewna, jak dawniej sądzono. Pod tym względem Strasser przechyla się ku krytyce Merleau-Ponty. Zdaniem Merleau-Ponty oczywistość o tyle tylko nam się jawi, o ile osoba ludzka na nią się otwiera. Ale osoba otwiera się na oczywistość jako egzystencja kosmiczna, historyczna, społeczna, kulturalna. Dlatego w każdej oczywistości kryje się niebezpieczeństwo subiektywizmu: oczywistość jest przede wszystkim oczywistością dla tego, który przeżywa daną intuicję w jej najrozmaitszych uwarunkowaniach i w swoistym horyzoncie ${ }^{10}$.

Nieodzownym uzupełnieniem zasady intuicji jest zasada dialektyczna. Antropologia fenomenologiczna winna być dialektyczną, tzn. ma się łączyć z metodyczną zmianą perspektywy. Dzięki dialektyce unika się jednostronnych perspektyw i ograniczonych horyzontów ${ }^{11}$. Dialektyka jest dialogiem niemym i słownym. Dialog niemy polega na tym, że człowiek sam sobie i rzeczom, wobec których staje jako wobec pewnej sytuacji, stawia pytania. W ten sposób zgodnie z założeniami fenomenologii rozpatruje się fenomen ludzki w jego różnych aspektach, perspektywach i w odmiennych stopniach jasności.

Dialog słowny jest zarazem pewnego rodzaju spotkaniem, bezpośrednim lub pośrednim (np. za pośrednictwem dokumentów historycznych), $\mathrm{w}$ sytuacjach naturalnych lub eksperymentalnych (konsultacja, ankieta). Fenomenologia spotkania (F. J. J. Buytendijk) jest dla Strassera czymś więcej, aniżeli tylko poznaniem określonej sytuacji ludzkiej: rzuca ona również pewne światło na metodę antropologii filozoficznej 12 .

Filozofia jest z istoty swej disputatio, kontrowersją. Dialog filozofów nie może istnieć bez różnicy opinii, gdyż sprzeciw jest duszą dialogu. Filozofowie tworzą wspólnotę duchową nie tyle przez zgodność poglądów, ile raczej przez wspólną aspirację, dążenie do mądrości. Przy tej disputatio, przy dialogu słownym, nawet krytyka niesłuszna może stać się pozytywną, gdyż umożliwia lepsze zrozumienie własnej wizji człowieka. Dialog nie zawsze daje wyniki pozytywne. Z natury rzeczy jest on próbą zrozumienia rzeczywistości ludzkiej, a próba może się nie udać. Rezultat próby, pozytywny lub negatywny, zależy od wielu warunków: historycznych, kulturalnych, społecznych. Dlatego dialektyka w ramach antro-

10 Phénoménologie, 261-263, 268-270. O poznaniu jako „otwieraniu się" por. J. Vande Wiele, Les structures fondamentales de la vie cognitive. Contribution à une anthropologie philosophique, „Revue Philosophique de Louvain”, 64 (1966) 96-129.

11 Phénoménologie, 265: „Par dialectique, nous entendrons, au contraire le changement méthodique de perspective qui permet à l'homme cherchant à atteindre le sens de dépasser systématiquemant les perspectives unilatérales et les horizonts limités".

12 Phénoménologie, 265-267, 156-160. Zagadnieniu spotkania poświęcona jest praca zbiorowa pt. Rencontre-Encounter-Begegnung, Utrecht-Antwerpen 1957. Strasser umieścił w niej artykuł pt. Gedankensplitter zu einer Phenomenologie des Scheidens, $465-471$. 
pologii filozoficznej może mieć charakter progresywny, ale także i regresywny. Ogólnie jednak mówiąc dialektyka filozoficzna, idąc różnymi drogami, wzbogaca skarb wiadomości o człowieku ${ }^{13}$.

Choć Strasser opowiada się za antropologią fenomenologiczną, to jednak uznaje pluralizm filozoficzny. Rzeczywistość ludzka jest tak bogata, że jeden kierunek filozoficzny, posługujący się jedną tylko metodą, nie jest w stanie poznawczo wyczerpać tej rzeczywistości. Dlatego uprawnione są różne kierunki filozoficzne i różne metody. Strasser sądzi, iż nie ma tu obawy jakiegoś relatywizmu, każdy bowiem prawdziwy filozof osiąga autentyczną prawdę: poznanie jego zawiera w sobie pewien aspekt prawdy, choć nie pełną prawdę.

Pluralizm filozoficzny nie oznacza też, że każdy kierunek ma jednakową wartość. Wartość danego kierunku mierzy się wkładem, jaki wnosi do dialogu poszukujących prawdy, do dialogu prowadzonego w ciągu wieków w ramach jednej cywilizacji lub ewentualnie także między wieloma cywilizacjami ${ }^{14}$. W przekonaniu Strassera największy wkład w skarb prawd o człowieku wnosi fenomenologia. Stąd można ją nazwać fundamentalną filozofią człowieka ${ }^{15}$.

Strasser krytykuje antropologię filozoficzną reprezentowaną przez neopozytywistów, głównie Carnapa, i filozofię człowieka Sartre’a. Carnap faktycznie usuwa, to co jest najbardziej specyficzne dla człowieka, sprowadzając język filozofii antropologicznej do języka nauk przyrodniczych i posługując się $\mathrm{w}$ tej filozofii metodą nauk przyrodniczych. Język nie jest systemem znaków neutralnych. Dlatego nie można jakiejkolwiek treści wkładać w jakikolwiek język. Metoda także, jako droga prowadząca do celu, winna być dostosowana do natury celu, którym w tym wypadku jest poznanie rzeczywistości ludzkiej. Głównym więc błędem filozofii człowieka Carnapa jest redukcjonizm, nieuprawnione usuwanie pewnych stron $\mathrm{i}$ to najważniejszych $\mathrm{z}$ fenomenu ludzkiego ${ }^{16}$.

Błąd redukcjonizmu odkrywa Strasser również w. filozofii człowieka Sartre'a. Wolność absolutna woli ludzkiej niezgodna jest z intuicją fenomenu egzystencji ludzkiej; do natury tej egzystencji należy przecież

13 Phénoménologie, 282, 235, 242-244, 266-267.

14 Phénoménologie, 241-242. O. M. A. Krąpiec słusznie zaznacza, że nawet krańcowo różne teorie z dziedziny antropologii filozoficznej „coś z rzeczywistości realnie afirmują", choć ostre i jasne widzenie $w$ tych teoriach łączy się zwykle $\mathrm{z}$ widzeniem wąskim i ciasnym. Por. Idee przewodnie we wspótczesnej filozofii człowieka, „Zeszyty Naukowe KUL”, 13 (1970), nr 4, 27-28 (nota).

15 Phénoménologie, 318: „Sur quoi repose alors notre affirmation que l'horizon herméneutique proposé par la phénoménologie, possède une certaine précellence? Nous avons déjà répondu par avance: elle repose sur le fait que la philosophie phénoménologique - et elle seule - est une philosophie fondamentale de l'existence humaine, et que cette philosophie possède un caractère de rigueur particulier".

16 Phénoménologie, 33-41. 
ograniczenie i zależność od rzeczy i innych ludzi. Egzystencja ludzka nie jest dowolnym następstwem całkiem samodzielnych projektów, akty wolne tej egzystencji nie są $\mathrm{w}$ pełnym tego słowa znaczeniu aktami stwórczymi. Świadomość ludzka jest świadomością potrzebującą czegoś lub kogoś. Człowiek zależy od jakiejś rzeczy, która stanowi dla niego normę. Swiadomość ludzka musi się otwierać wobec jakiegoś bytu, by przeżyć takie lub inne doświadczenie. Egzystencja ludzka przybiera postawę receptywną, pozwala się prowadzić przez to, co ujmuje w swym doświadczeniu, uzyskuje od rzeczy odpowiedzi na swe pytania, takie odpowiedzi, które stają się jej regułami poznania i działania.

Potrzebująca świadomość ludzka jest także zależna od innych świadomości. W dialogu z innymi determinuje się przedmiot naszego doświadczenia wspólnego: przedmiot ten pojawia się jako identyczny, ale zarazem jako posiadający różne ,aspekty”. Co więcej, dzięki mowie jednostka ludzka dysponuje ogólnymi punktami widzenia, które pozwalają jej porównywać swoje doświadczenie $z$ doświadczeniem innych i porządkować to doświadczenie. Porównanie zaś takie nadaje nowe wymiary własnemu doświadczeniu. Dialog np. nadaje miłości danej osoby znaczenie etyczne i społeczne, którego przedtem nie miała. A znaczenie takie staje się z kolei dla tej osoby regułą praktyczną i teoretyczną.

Sytuacja zależności nie jest jakąś heteronomią. Nie chodzi tu o prawo obce, nadchodzące $\mathrm{z}$ zewnątrz. Przeciwnie jednostka ludzka domaga się tego prawa na mocy swego wewnętrznego prawa, gdyż jest $\mathrm{z}$ istoty swej egzystencją zależną ${ }^{17}$.

Między antropologią pozytywną a filozoficzną nie ma wyraźnej linii granicznej, można tu raczej mówić o strefie przygranicznej ${ }^{18}$. Ostatnie stadium pracy empirycznych nauk o człowieku, tzw. wizja całościowa, zawiera już faktycznie pewne elementy filozoficzne. Przy tej głównie wizji spotykają się zdaniem Strassera filozof i przedstawiciel antropologii pozytywnej. Współpraca jednak empirycznych nauk o człowieku i filozofii człowieka nie ogranicza się tylko do wizji całościowej: jest bardziej wszechstronna i daleko idąca. Nie ma prawdziwej empirycznej nauki o człowieku bez momentów filozoficznych i nie istnieje autentyczna antropologia filozoficzna, która by nie uwzględniała rezultatów nauk empirycznych ${ }^{19}$.

Antropologia filozoficzna może oddać znaczne usługi empirycznym naukom o człowieku, gdyż oczyszcza ich doświadczenie z nieuzasadnio-

17 Phénoménologie, 95-96. Strasser, podobnie jak Heidegger, podkreśla znaczenie mowy $w$ filozofii. O znaczeniu mowy $w$ filozofii Heideggera por. L. Fontaine - De Visscher, La pensée du langage chez Heidegger, „Revue Philosophique de Louvain", 66 (1966) 225-262.

18 Phénoménologie, 298-300.

19 Phénoménologie, 237-238, 253-256, 216-218. 
nych teorii, hipotez i uprzedzeń, które szkodzą rezultatom tych nauk. Prócz tego filozofia człowieka dostarcza antropologii pozytywnej zasadniczych pojęć. Etnologia np. opisuje mit, ale nie jest w stanie przy pomocy własnych metod dotrzeć do istoty mitu. Mit można ujmować rozmaicie: jako twór kapłanów, przejaw archetypów (Jung), jako wyraz dynamizmu bio-kulturalnego lub jako odczucie zależności od wyższych sił. Filozofia tłumaczy, czym jest mit sam w sobie i ukazuje ścisłe pojęcie mitu etnologii 20 .

$\mathrm{Z}$ drugiej strony antropologia filozoficzna czerpie materiał $\mathrm{z}$ nauk empirycznych. Struktury fundamentalne, uzyskane drogą metody fenomenologicznej, byłyby zbyt abstrakcyjne i nie mogłyby stanowić prawdziwej antropologii filozoficznej. Filozofia człowieka potrzebuje surowca w postaci rezultatów antropologii pozytywnej. Zresztą zdaniem Strassera wszyscy wybitni fenomenologowie sięgają po te rezultaty. Husserl np., porównując w swym dziele „Kryzys nauk europejskich” cywilizację Europy z cywilizacją starożytnych Indii, opiera się na danych historycznych. Dane historyczne stanowią dla niego noematy określonych funkcji noetycznych, które zostały zanalizowane wcześniej w innym kontekście ${ }^{21}$.

Współpraca między antropologią filozoficzną i pozytywną jest dziś bardziej możliwa niż w innych czasach. $\mathrm{Z}$ jednej bowiem strony coraz mniej jest takich przedstawicieli nauk empirycznych o człowieku, którzy by uważali, że nauki te mogą rozwiązać wszystkie problemy egzystencji ludzkiej, a z drugiej strony rzadkie już są wypadki filozofów budowniczych systemów. Powściągliwość i skromność z jednej i drugiej strony stwarza odpowiedni klimat duchowy dla zgodnej współpracy ${ }^{22}$. Owocny dialog między naukami humanistycznymi a antropologią filozoficzną zależy od pewnych warunków. Z jednej strony filozof winien pogłębić dziedzinę specjalnego doświadczenia humanisty, poznać jego ważniejsze metody, podstawowe pojęcia i znaczenie techniczne jego koncepcji. „Trzecia obiektywwność” filozofii winna opierać się na znajomości określonych dziedzin ,drugiej obiektywności”. To samo dotyczy przedstawiciela antropologii pozytywnej. Humanista ma obowiązek zapoznać się z pojęciami, metodami i językiem tego kierunku filozoficznego, którego ważność uznaje åla rozpracowania własnej problematyki ${ }^{23}$.

20 Phénoménologie, 284, 216-217, 313-318.

21 Phénoménologie, 285-287. O punkcie wyjścia w antropologii filozoficznej por. A. B. Stępień, Wprowadzenie do metafizyki, Kraków 1964, 137-138; S. Kamiński, Antropologia filozoficzna a inne działy poznania, w: O Bogu i c człowieku, I, $161-162$.

22 Phénoménologie, 239: „Nous sommes convaincu que la possibilité d'un rapprochement entre les sciences empiriques et la philosophie est de nos jours plus grande qu'elle n'a été jadis, en raison même de la modestie dont on fait preuve de part et d'aultre".

23 Phénoménologie, 249. 
Do szczegółowych zagadnień antropologii filozoficznej Strassera należą: zagadnienie jaźni i uczuć. Oba zagadnienia omawia Autor z punktu widzenia historycznego, przeprowadzając wnikliwą analizę krytyczną wybranych poglądów, jak również od strony systematycznej. W pracy poświęconej jaźni centralnym tematem jest przedmiot psychologii empirycznej i metafizycznej. Rozwijając to zagadnienie historycznie omawia najpierw Autor poglądy od Kartezjusza po Gabriela Marcela. M. in. uwzględnia tematykę psychologiczną Kanta, Husserla i J. Geysera. Część systematyczna obejmuje problem jaźni jako autora swych aktów, zagadnienie inkarnacji jaźni oraz studium dotyczące ja jako bytu duchowego.

Zdaniem Strassera przedmiotem psychologii metafizycznej jest actus transcendentalis, który stanowi istotę naszego ja duchowego. Ja jako akt transcendentalny wykracza poza środowisko naturalne i spoleczne i ujmuje byt $\mathrm{w}$ jego aspektach absolutnych. Przedmiotem natomiast psychologii empirycznej są obiektywacje lub quasi obiektywacje, w których akt transcendentalny uzewnętrznia się. W obiektywacjach lub quasi obiektywacjach duch ludzki nie przejawia się w sposób adekwatny, obiektywacje te są jak gdyby negatywem bytu duchowego. W tym celu, by dotrzeć do tego, czym jest świadomość od strony pozytywnej, trzeba rozważań natury metafizycznej. Negatyw ten jednak jest konkretnie dostrzegalny, daje duże bogactwo szczegółów i tym samym stanowi cenny materiał ${ }^{24}$.

Sądy psychologii metafizycznej i empirycznej nie sprzeciwiają się sobie, lecz wzajemnie się uzupełniają. Między psychologią empiryczną i metafizyczną winna istnieć ścisła współpraca. Taka jedynie współpraca może doprowadzić do powstania antropologii filozoficznej naukowo uzasadnionej, współczesnej i bliskiej życiu ${ }^{25}$.

Przedstawiając drugie zagadnienie szczegółowe, teorię uczuć, podaje Autor, podobnie jak i przy pierwszym temacie, ważniejsze poglądy odnoszące się do strony emocjonalnej człowieka. Analiza krytyczna Autora dotyczy przede wszystkim Schelera i Sartre'a, gdyż ich poglądy silnie zaważyły na współczesne ujęcie życia uczuciowego. Zresztą rozważania historyczno-krytyczne Autora nie stanowią jakiejś samodzielnej jednostki w problematyce uczuciowej: ich zadaniem jest przygotować drogę refleksjom systematycznym, do których przykłada największą wagę.

W części systematycznej stwierdza Strasser, że jego rozważania na temat uczuć są tylko współczesną, choć swobodną interpretacją traktatu św. Tomasza „De passionibus”. Faktycznie Autor na tle tekstów tomistycznych rozwija oryginalną teorię uczuć. Temat logos i pathos jest jed-

24 Le problème de l'âme, 236-239.

25 Le problème le l'âme. 239: „Seule une étroite collaboration entre le philosophe et le psychologue peut faire naître une anthropologie proche de la vie, scientifiquement légitimée et moderne, qui décrive l'homme concret dans sǫn unité organico-spirituelle". 
nym z zagadnień tej teorii. Zdaniem Autora „,racje rozumu” i ,racje serca" nie są od siebie ściśle oddzielone. Przeciwnie pełne poznanie dokonuje się normalnie $\mathrm{w}$ ten sposób, że racjonalne i nieracjonalne czynniki zespalają się w jednolity obraz świata. Przy poznaniu czystych faktów występuje pewnego rodzaju epoche, o ile moment wartości sztucznie się pomija. Przy poznaniu zaś całościowym, a takie poznanie ma miejsce szczególnie w teorii człowieka, ujmuje się moment wartości, przy czym udział bierze życie emocjonalne ${ }^{26}$. Z tego jednak nie wynika, że należy przyjąc jakąś ,logikę uczuć”, odrębną od logiki rozumu. Strasser krytykuje teorię ,logiki uczuć” Th. Ribot 27 i nie przypisuje uczuciom energii poznawczych.

Zdaniem Strassera nie można podać pełnej inwentaryzacji uczuć. Rzeczywistość bowiem, w związku z którą budzą się uczucia, jest bardzo bogata i wciąż się tworzy. Prócz tego dokonuje się ewolucja jednostek, kultur i grup społecznych, z czym się łączy powstawanie różnych odmian życia uczuciowego. Można natomiast podać typologię uczuć: da się ją zbudować w oparciu o zabieg fenomenologiczny, zwany od czasów Husserla wariacją imaginacyjną.

Strasser wyróżnia m. in. nastroje (Stimmungen), uczucia intencjonalne (Gesinnungen), postawy fundamentalne (Grundhaltungen) i namiętności (Leidenschaften). Wiele miejsca poświęca opisowi i typologii szczęścia oraz pokrewnych przeżyć, takich jak radość, rozkosz lub uczucia związane $\mathrm{z}$ dokonaniem. Opis strony uczuciowej łączy się z ich hermeneutyką. Autor widzi sens doświadczenia szczęścia w antycypacji transcendentnej (Vorgriff) ${ }^{28}$. Godne uwagi są również rozważania Autora na temat warstw i poziomów życia uczuciowego ${ }^{29}$.

W poglądach Strassera wyraźnie zjawia się zasada szacunku filozoficznego, którą można uznać za cechę charakterystyczną fenomenologii 30. Duch szacunku dotyczy najpierw samej rzeczywistości ludzkiej. Strasser sądzi, że należy dążyć do poznania pełnego fenomenu ludzkiego. W związku z tym krytycznie odnosi się do wszystkich kierunków, które dążą do zubożenia tego fenomenu. Scientyzm, behawioryzm, operacjonizm i pokrewne im poglądy nie dostrzegają zdaniem Strassera w egzystencji ludzkiej tego, co jej jest najbardziej właściwe. Szacunek dla rzeczywi-

${ }_{26}$ Das Gemüt, 74, 80. Por. A. R. Dilanni, L'analyse du langage et les jugements moraux dans l'oeuvre de R. M. Hare, „Revue Philosophique de Louvain", 68 (1967) 330 .

27 Das Gemüt, $175 \mathrm{nn}$.

28 Das Gemüt, 264.

29 Por. Spiegelberg, II, 605.

30 Por. Spiegelberg, II, 701: „What distinguishes phenomenology from other methos is not so much any particular step it develops or adds to them but the spirit of philosophical reverence as the first and foremost norm of the philosophical enterprise. The violation of this norm in a age of reductionisme constituted the raison d'être for phenomenology at the time of its birth". 
stości ludzkiej jest zresztą tylko zastosowaniem hasła Husserla: „Z powrotem do rzeczy".

Szacunek filozoficzny przejawia się również w pozytywnej ocenie każdego wysiłku zmierzającego do poznania człowieka. Zdaniem Strassera należy cenić każdą uczciwą próbę filozoficznego poznania egzystencji ludzkiej. Nicolai Hartmann zaznacza, że uwarunkowanie czasowe opinii i systemów nie sprzeciwia się trwałej wartości uzyskanych myśli, nawet wtedy, gdy te myśli występują w systemach i opiniach tylko sporadycznie ${ }^{31}$. Podobną postawę zajmuje Strasser, uważając najwidoczniej, że prawda bardziej jest rozpowszechniona niż się zwykle sądzi, że można ją odkryć nawet w błędnych systemach.

Zdaniem Strassera historia filozofii nie jest zbiorem błędów, lecz szlachetną próbą, stale ponawianą, zrozumienia tajemnicy człowieka. Sądy różnych filozofów, pozornie sprzeczne, nie są często takimi, gdyż nie odnoszą się do tej samej rzeczywistości lub przynajmniej nie do tych samych aspektów rzeczywistości ${ }^{32}$. Każdy filozof winien przyznać, że obok jego próby rozwiązania istnieją jeszcze inne interpretacje, inne próby pochodzące z odmiennej sytuacji historycznej, od innego doświadczenia egzystencjalnego lub innego temperamentu filozoficznego. Nawet myśliciel, reprezentujący określoną tradycję filozoficzną, winien przyznać, że inne umysły, należące zresztą do tej samej rodziny, w inny sposób tłumaczą fundamentalne pojęcia tej tradycji ${ }^{33}$.

Słusznym postulatem Strassera jest postulat współpracy antropologii filozoficznej z naukami empirycznymi o człowieku. Według Strassera nie należy porównywać nauk o człowieku do przedziału szczelnie zamkniętego, do dyscyplin, które nic nie czerpią z doświadczenia przednaukowego czyli z tzw. pierwszej obiektywności i odcinają się od tego wszystkiego, co w jakikolwiek sposób przypomina metafizykę. Przeciwnie wiedza jest drzewem, które swą siłę czerpie z gleby doświadczenia przednaukowego a konarami swymi dotyka problematyki filozoficznej ${ }^{34}$. Porównanie to dotyczy wprost nauk empirycznych o człowieku, uzmysławia fakt, że nauki te korzystają $\mathrm{z}$ doświadczenia przednaukowego i filozoficznego. Strasser jednak wielokrotnie akcentuje również stosunek odwrotny, tzn. zależność filozofii człowieka od antropologii pozytywnej.

Faktycznie antropologia filozoficzna, jak wykazuje jej historia, tradycyjnie wiązała się z licznymi naukami empirycznymi o człowieku. Współczesna zaś filozofia człowieka ma pod tym względem jeszcze większe

31 Der philosophische Gedanke und seine Geschichte, Berlin 1936, 15.

32 Phénoménologie, 242-243. R. Ingarden slusznie napisał, że „nic w wiekowej pracy filozoficznej nie idzie na marne, co zostało podjęte z silną wolą osiągnięcia prawdy", Z badań nad filozofia wspótczesna, Warszawa 1963, 290.

33 Phénoménologie, 240.

34 Phénoménologie, 195. 
możliwości. Zagadnienie np. osobowości i związany z tym problem integracji i dezintegracji omawia $\mathrm{m}$. in. współczesna socjologia ${ }^{35}$. Rezultaty jej badań, odpowiednio przepracowane, może wykorzystać filozofia człowieka.

P. Ricoeur nazwał Strassera „człowiekiem konfrontacji” ${ }^{36}$, mając przede wszystkim na uwadze jego zestawienie i porównanie tematów tomistycznych z fenomenologią. W rzeczywistości Strasser chętnie korzysta z tekstów św. Tomasza i komentuje je metodą fenomenologiczną. Wielkie zresztą tezy antropologii tomistycznej uważa za uzasadnione w całej pełni ${ }^{37}$.

Strasser nie posuwa się od antropologii tradycyjnej ku współczesnej problematyce, lecz odwrotnie od problematyki współczesnej ku tezom tradycyjnym. Taki sposób postępowania, jak się zdaje, jest właściwy głównie z tego powodu, że bardziej odpowiada potrzebie reinterpretacji i zdrowej modernizacji tematów przekazanych przez tradycję. Można sądzić, że metoda podana przez Strassera wskazuje właściwą drogę kształtowaniu się współczesnej antropologii filozoficznej w ramach filozofii chrześcijańskiej.

Zdaniem Strassera koniecznym założeniem współczesnej filozofii człowieka jest zerwanie z Kartezjańską koncepcją człowieka ${ }^{38}$. Słuszne to założenie ma swe pokrycie w licznych tekstach tradycyjnych. Według św. Tomasza człowiek nie może być określony jako dusza ${ }^{\mathbf{3 9}}$, samej też duszy nie przysługuje ani definicja ani nazwa osoby ${ }^{40}$, doskonalszym jest również (ceteris paribus) stan duszy w jej połączeniu z ciałem, aniżeli w odłączeniu od ciała ${ }^{41}$. W związku z tym można powiedzieć, że przyczyny wtórne narzucają duszy jednostkowej ,jej szczegółowe piętno (tale esse)" 42. Tego rodzaju ujęcie natury ludzkiej, powiązane ze współczesną

35 Por. J. Szczepański, Elementarne pojęcia socjologii, Warszawa 1970, 128-142; A. Kłoskowska, Z historii $i$ socjologii kultury, Warszawa 1969, 195-262. O znaczeniu nauk empirycznych dla antropologii filozoficznej por. S. Kamiński, O koncepcjach filozofii człowieka, ,Zeszyty Naukowe KUL", 13 (1970), nr 4, 9, 17-18; Wł. Osiński, Antropologia filozoficzna. Nowa nauka o człowieku, Znak, 15 (1963) $1259-1262$.

36 Przedmowa do Phénoménologie, 7.

37 Le problème de l'âme, 190.

38 Phénoménologie, 19.

39 I q. 75 a. 4.

40 I q. 29 a. 1 ad 5: „Et sic non competit ei neque definitio personae, neque nomen”. Por. I q. 75 a. 4 ad 2: „Ad secundum dicendum quod non quaelibet substantia particularis est hypostasis vel persona: sed quae habet completam naturam speciei. Unde manus vel pes non potest dici hypostasis vel persona. Et similiter nec anima, cum sit pars speciei humanae".

41 Suppl. q. 75 a. 1 ad 4: ,Ad quartum dicendum quod, ceteris paribus, perfectior es' status animae in corpore quam extra corpus". Por. refleksje G. Gusdorfa na temat inkarnacji ducha ludzkiego. Traité de métaphysique, Paris 1956, 210-249.

42 Por. Ks. K. Kłósak, Teoria kreacjonistycznych początków duszy ludzkiej a wspótczesny ewolucjonizm, "Analecta Cracoviensia", 1 (1969) 53. Por. I q. 85 a. 7 : „Manifestum est enim quod quanto corpus est melius dispositum, tanto meliorem sortitur animam". 
problematyką osobowości i z klasyczną definicją osoby, może stanowić dobry punkt wyjścia dla centralnej tematyki filozofii człowieka.

\section{S U M M A R I U M}

DE ANTHROPOLOGIA PHILOSOPHICA A STEPHANO STRASSER PROPOSITA

S. Strasser suam hominis philosophiam praesertim in tribus sequentibus libris proponit: „Phénoménologie et sciences de l'homme" (1967); „Le problème de l'âme” (1953); „Das Gemüt” (1956). His in operibus phenomenologiam ante omnia, tamquam fundamentalem existentiae humanae philosophiam, aestimat. In expositione tamen Auctoris etiam textus S. Thomae aliorumque philosophorum suum locum habent.

In primo opere indolem scientiarum empiricarum de homine et philosophiae hominis eorumque mutuam relationem deliberat. Iuxta Auctorem anthropologia philosophica indolem hermeneuticam, intuitivam et dialecticam habet. Inter scientias empiricas de homine et philosophiam hominis intima connexio et cooperatio existere debet. Strasser anthropologiam a Carnap et Sartre propositam ampliori analysi subicit.

In duobus ulterioribus libris Strasser quasdam particulares anthropologiae philosophicae quaestiones considerat et quidem obiectum psychologiae empiricae et metaphysicae necnon theoriam passionum et affectuum examinat. 